\title{
Comfortable climatic conditions for human on the territory of Ukraine for the period $1991-2020$
}

\author{
S. Boychenko ${ }^{1,2}$, O. Zabarna ${ }^{3}$, T. Kuchma ${ }^{4}, 2021$ \\ ${ }^{1}$ S.I. Subbotin Institute of Geophysics of the National Academy of Sciences of Ukraine, \\ Kyiv, Ukraine \\ ${ }^{2}$ National University of Kyiv-Mohyla Academy, Kyiv, Ukraine \\ ${ }^{3}$ Central European University, Budapest, Hungary \\ ${ }^{4}$ Institute of Agroecology and Natural Management of the National Academy \\ of Agrarian Sciences of Ukraine, Kyiv, Ukraine
}

Received 22 June 2021

The ecological state of the environment, climatic conditions with pronounced seasonality, variability, anomaly summer heat and regional manifestations of climate change, have a certain negative impact onwell-being, health and comfort of the population. To assess climatic comfort of a person, a bioclimatic index (equivalent-effective temperature) was used, which allows evaluating thermal sensation of a person under a certain combination of meteorological parameters. In this study we used daily observation data (surface temperature, air humidity and wind velocity) at 34 meteorological stations in Ukraine for the period 1991 — 2020 . Analysis and ranging of data, which characterize the thermal bioclimatic conditions, were done.

It was found that the weather conditions with apparent temperature of very cold-coldcool - slightly cool comprise about $268 \pm 9$ (73\%) days per year. Thus, the population of Ukraine experience conditions of physiologically cold stress during most of the year. Weather conditions that fall into gradations very cold $-(30-23)$ and cold $-(23-12)$ represent $6 \pm 5$ $(\sim 2 \%)$ and $42 \pm 17(\sim 12 \%)$ days per year respectively. They can consequently cause extreme cold and strong cold stress and have a tendency towards decreasing repeatability.

The largest number of days on average across the country have such gradations as slightly cool 0-12 and cool -(12-0), $113 \pm 10(31 \%)$ and $107 \pm 8(29 \%)$ days per year respectively. Slightly cool weather conditions are typical for the warm period of the year, mainly autumn and spring, and partially winter, while cool-(12-0) is more prevalent in winter, autumn and spring seasons.

Comfortable and subcomfortable thermal conditions with apparent temperature of slightly warm and warm compose on average $96 \pm 8(\sim 26 \%)$ days per year. Comfortable thermal conditions represent about $47 \pm 13(13 \%)$ days per year and are typical for the warm period from April to October, with maximal values in summer: June $10 \pm 3$, July $17 \pm$ \pm 4 and August $15 \pm 4$ days per month. A number of days with subcomfortable thermal conditions comprise also $48 \pm 3$ (13\%) days per year. Moreover, for May-September the number of days per month is almost stable from 7 to 12 with minimal values in April, October and November, about $1-2$ days. There is a tendency to increase in the number of days with comfortable thermal conditions in summer by $0.2-0.3$ days per month for this period. The trend is 0.83 days per year (on average 25-30 days were added each year) for the period 1991-2020. Thus, comfortable climatic conditions for the local population in Ukraine increase during the warm season.

However, the frequency of hot apparent temperatures (23-30) has increased, especially during yhe summer period, which can subsequently cause strong and extreme heat stress for humans. In some years, it was recorded up to 5-19 days per year.

For that reason, the climatic conditions of Ukraine have a certain potentially comfortable climatic resource(in June-August): the Western region has a minimal climatic resource (23-40\%); the Northern region has a sufficient climatic resource (36-53\%); Central region has an optimal climatic resource (40-60\%); and the Southern region has an optimal climatic resource $(40-67 \%)$.

Key words: climate change, equivalent-effective temperature, comfortable and subcomfortable weather conditions, trends. 
Introduction. Currently, a high level of concern among scientists exists due to the increasing impact of climate change on human health [WHO ..., 2005; IPCC ..., 2013]. People's exposure and vulnerability to different health threats depends on regional characteristics of the environment, level of awareness, availability of financial resources as well as management efficiency and quality of infrastructure.

Due to climate change, the role of thermal environment and outdoor thermal comfort will have a significant importance in urban population's daily life and social well-being. Projections of Intergovernmental Panel on Climate Change [IPCC ..., 2013] show that at the end of 21 st century there will be an increase in the global mean surface air temperature by 2.0 to 4.8 - that will have a direct impact on the changing conditions of the thermal comfort in urban areas.

Moreover, the situation will deteriorate due to pervasive phenomena of «heat waves», especially in urbanizes territories. Climate change nowadays results in more frequent and intense heat waves in comparison to the past century [Koffi, Koffi, 2008; Lemonsu et al., 2014] that cause an emerging public-health problem. For instance, one of the largest spikes in excess heat-related deaths was noted in Europe during the summer of 2003 [Canoui-Poitrine et al., 2006]. In particular, for the period of 11 extremely hot days in August 2003 the rate of mortality reached over 14947 deaths in France [Poumadere et al., 2005].

Significant heat stress may also cause the development of heatstroke, heat exhaustion, heat syncope, and heat cramps [Kovats, Hajat, 2008]. It is worth noting that the periods of extreme heat are often associated with an increase in emergency hospital admissions [Johnson et al., 2005]. Particularly, among the elderly this number increased considerably during the heat wave in August 2003 in Spain [Cajoto et al., 2005] and in France [Gremy et al., 2004].

Thermal comfort is "a condition of mind which expresses satisfaction with the thermal environment» [Epstein, Moran, 2006]. It is a subjective sensation which influences the working capacity, health and life span of the individual. Sensation of the thermal comfort is attributable to 3 main parameters such as: heat balance of the body, sweat rate, and mean skin temperature [Fanger, 1970]. Any deviations that are outside of the comfort limits may cause the feeling of discomfort. In order to assess thermal comfort for human being, a number of bioclimatic indices have been developed.

Populations in different climate zones experience the different level of heat stress due to variations in such meteorological parameters as air temperature, humidity, solar radiation, wind velocity, etc. Heat load directly depends on latitude; however, it can also be influenced by altitude [Jendritzky, Tinz, 2009]. People who live in the tropics, experience the highest number of days with heat load during the year, but due to climate change, in moderate latitudes the number of days with heat stress will also increase in future [Jendritzky, Tinz, 2009].

For example, it was found that there is a shift from «no thermal stress» to «moderate thermal stress and strong thermal stress» in Hong Kong due to climate change [Cheung, Hart, 2014]. Other studies show that Miami [Huang et al., 2020] had a very high frequency of moderate and strong unacceptable heat stress $(54.7 \%)$, while in Gothenburg the overall hours of «no thermal stress» increased [Thorsson et al., 2011]. Heat load index in Serbia defined stressful thermal conditions in July 2011 on six different weather stations [Pecelj, 2012; Pecelj et al., 2013]. Increased values were also fixed in 2000 and 2007 in Loznica, Belgrade, Novi Sad [Milovanović et al., 2017]. Likewise, thermal comfort in Poland increased significantly during heat waves in 2011, 2013, 2015 and 2016 [Rymuza et al., 2019].

Taking into consideration Ukraine, it was reported that during the period of 2006-2018, a shift by $10-15 \%$ cases towards more comfortable climate in Kyiv was identified [Boychenko, Zabarna, 2019].

The main aim of the research is to analyze the patterns and trends of spatial-temporal distribution of comfortable thermal bioclimat- 
ic conditions for human within the territory of Ukraine during the period 1991-2020.

Materials and methods. A number of bioclimatic indices were developed in an attempt to assess conditions for humanbased on heat budget models. For instance, such indices as Universal Thermal Climate Index (UTCI), Standard Effective Temperature (SET), Physiological Equivalent Temperature (PET), Perceived Temperature (PT), Physiological Subjective Temperature (PST), etc. are widely used nowadays [Fanger, 1970; Matzarakis, Amelung, 2008; Blazejczyk et al., 2012].

In this research, in order to assess the climatic comfort for human in a given region, the bioclimatic index Equivalent-Effective Temperature (hereinafter $I_{\mathrm{EET}}$ ) was used. It was calculated in accordance with Missenard formula [Missenard, 1933, Rymuza et al., 2019]:

$$
\begin{aligned}
I_{\mathrm{EET}}=37 & -\frac{37-t}{0.68-0.14 F+\frac{1}{1.76+1.4 v_{2}^{0.75}}} \\
& -0.29 t(1-F), \quad F=\frac{f}{100},
\end{aligned}
$$

where $t$ - daily variables of mean temperature $\left({ }^{\circ} \mathrm{C}\right), f$ - relative humidity $(\%), v_{2}$ - wind velocity $(\mathrm{m} / \mathrm{s})$, calculated for the height of $2 \mathrm{~m}$.

This index allows assessing the thermal sensation of an average person protected by standard clothing for a certain season, in certain weather conditions in the shade. It takes into account various combinations of meteorological parameters, such as: surface air temperature, relative air humidity and wind velocity.

In this article daily empirical data (surface temperature, air humidity and wind velocity) from the network of meteorological observation stations on the territory of Ukraine for the period of 1991 - 2020 were used in order to calculate $I_{\mathrm{EET}}$ (source [Weather ..., 2021; World ..., 2021]). 34 meteostations were selected in accordance with the following criteria: the stations are evenly located on the territory of Ukraine and their height above the sea level does not exceed $350 \mathrm{~m}$. The $I_{\text {EET }}$ values were afterward ranked by gradations (Table 1).

It should be noted that a special emphasis is done on the spatial-temporal distribution patterns of comfortable thermal and subcomfortable thermal conditions for human. It is considered that for temperate latitudes, including the territory of Ukraine, comfortable thermal conditions for human (with low activity) have $I_{\mathrm{EET}}$ values (16-23). Subcomfortable thermal

T a b l e 1 . Ranges of the Index of Equivalent-Effective Temperatures ( $\left.I_{\mathrm{EET}}\right)$ for different grades of apparent temperature for human [Epstein, Moran,2006; Isayev, 2001]

\begin{tabular}{|c|c|c|}
\hline Gradations of $I_{\mathrm{EET}}$ & Apparent temperature & Degrees of physiological stress \\
\hline$-(30.0-23.1)$ and -30.0 & Very cold & Extreme cold stress \\
$-(23.0-12.1)$ & Cold & Strong cold stress \\
$-(12.0-0.1)$ & Cool & Moderate cold stress \\
$0-12.0$ & Slightly cool & Slight cold stress \\
$12.1-16.0$ & Slightly warm & Subcomfortable thermal condition \\
$16.1-23.0$ & Warm & Comfortable thermal condition \\
$23.1-30.0$ & Hot & Strong heat stress \\
$>30.1$ & Very hot & Extreme heat stress \\
\hline
\end{tabular}

Note: Hereinafter extreme gradations are combined and presented as: $-(30-23),-(23-2),-(12-0)$, $0-12,12-16,16-23$ and $23-30$. 
conditions for human with values (12-16) can also be considered as comfortable if a person is active [Isayev, 2001; Vitchenko, Telesh, 2017]. Hereinafter we refer to these variables as $I_{\mathrm{EET}(16-23)}$ and $I_{\mathrm{EET}(12-16)}$ while to a number of days in each gradation as $N_{(16-23)}$ and $N_{(12-16)}$ respectively.

During the last couple of decades due to climate change, hot thermal conditions that have astrong heat stress for human became more intensive. That is why, the analysis of $I_{\text {EET (23-30) }}$ values with a number of days in the gradation $N_{(23-30)}$ was also included.

Considering natural, climatic and orographic conditions, we defined 4 regions in Ukraine: Western, Northern, Central and Southern. From the beginning of 2013, the meteorological data from the most part of Eastern region is not available, so this region had to be excluded. A number of functional stations of the Eastern region were relocated to the nearest regions (Table 2). However, during mapping an interpolation of data from nearest stations was applied.

Moreover, for comfortable thermal and subcomfortable thermal conditions 2 maps were created. To develop these maps the thin plate spline interpolation method was applied using ArcGIS desktop 10.7 software. This method produces the smooth surface based on input values and proved to be affective for continuous variables, if there is no additional parameter that required manual tuning [Franke, 1982]. It is widely used for the interpolation of weather data from meteorological stations network, especially in case of sparce input point distribution [Boer et al., 2001].

Results. The thermal bioclimatic conditions of Ukraine. For the territory of Ukraine $I_{\text {EET }}$ values were calculated according to equation (1). It characterizes the thermal bioclimatic conditions at the given meteorological stations for the period $1991-2020$ and are ranked in accordance with Table 1.

The distribution of days in a year according to $I_{\mathrm{EET}}$ gradations with different conditions of thermal comfort for 4 separate regions and the whole territory of Ukraine are averaged over the period 1991-2020 and are shown in Fig. 1, $a$ and Table 2 .
It was found that over the territory of Ukraine the largest number of days per year fall into gradations "slightly cool» $(0-12)$ and «cool»-(12-0) with $112 \pm 10(31 \%)$ and $106 \pm$ \pm 6 (29\%) days per year respectively.

The thermal bioclimatic conditions identified as «slightly cool» are typical for the warm period, mainly during autumn and spring and partly in winter due to the significant warming in the cold period of the year. Moreover, the number of days in gradation "slightly cool» has it maximum in the Western region (124 \pm \pm 6 days per year) with the highest values at particular meteorological stations such as Uzhhorod - 136 \pm 18 and Lviv $-127 \pm 15$ days per year. There are $110 \pm 7$ such days per year in the Northern region (Sarny - 123 \pm 12 and Zhytomyr - 118 \pm 12 days per year), and $108 \pm$ \pm 7 days per year in the Central region (Mohyliv-Podilskyi - 126 \pm 10 and Uman - $120 \pm 11$ days per year), and $106 \pm 7$ days per year in the Southern region (Simferopol $-116 \pm 9$ and Chornomorske $-111 \pm 10$ days per year).

"Cool» conditions are typical for cold period and partially warm period with maximum values in the Western and Northern regions reaching $109 \pm 6$ days per year (Lviv $-127 \pm$ \pm 15 and Sarny - 119 \pm 12 days per year), while in the Central and Southern regions it is about 102-107 days per year.

Weather conditions falling into gradations «very cold»-(30-23) and «cold»-(23-12) compose $5 \pm 3(1.5 \%)$ and $44 \pm 16$ (12\%) days per year respectively. In detail, Northern and Western regions have 5-6 days per year in gradation - $(30-23)$ and $45-46$ days per year in gradation -(23-12), while Central region has $7 \pm 4$ and $46 \pm 20$ days per year, and Southern has $4 \pm 2$ and $37 \pm 9$ days per year, respectively. These weather conditions are typical for winter period and can cause strong and extreme cold stress for human.

Therefore, the local population living in this area undergoes the thermal bioclimatic conditions of extreme cold - strong, cold-moderate, and cold - slight cold stress over the most part of the year $-268 \pm 9(73 \%)$ days per year.

During the warm period of the year, weather conditions that fall into gradations «sli- 
T a b l e 2. Distribution of a number of days due to $I_{\text {EET }}$ gradations at the meteostations of Ukraine, averaged for the period $1991-2020$

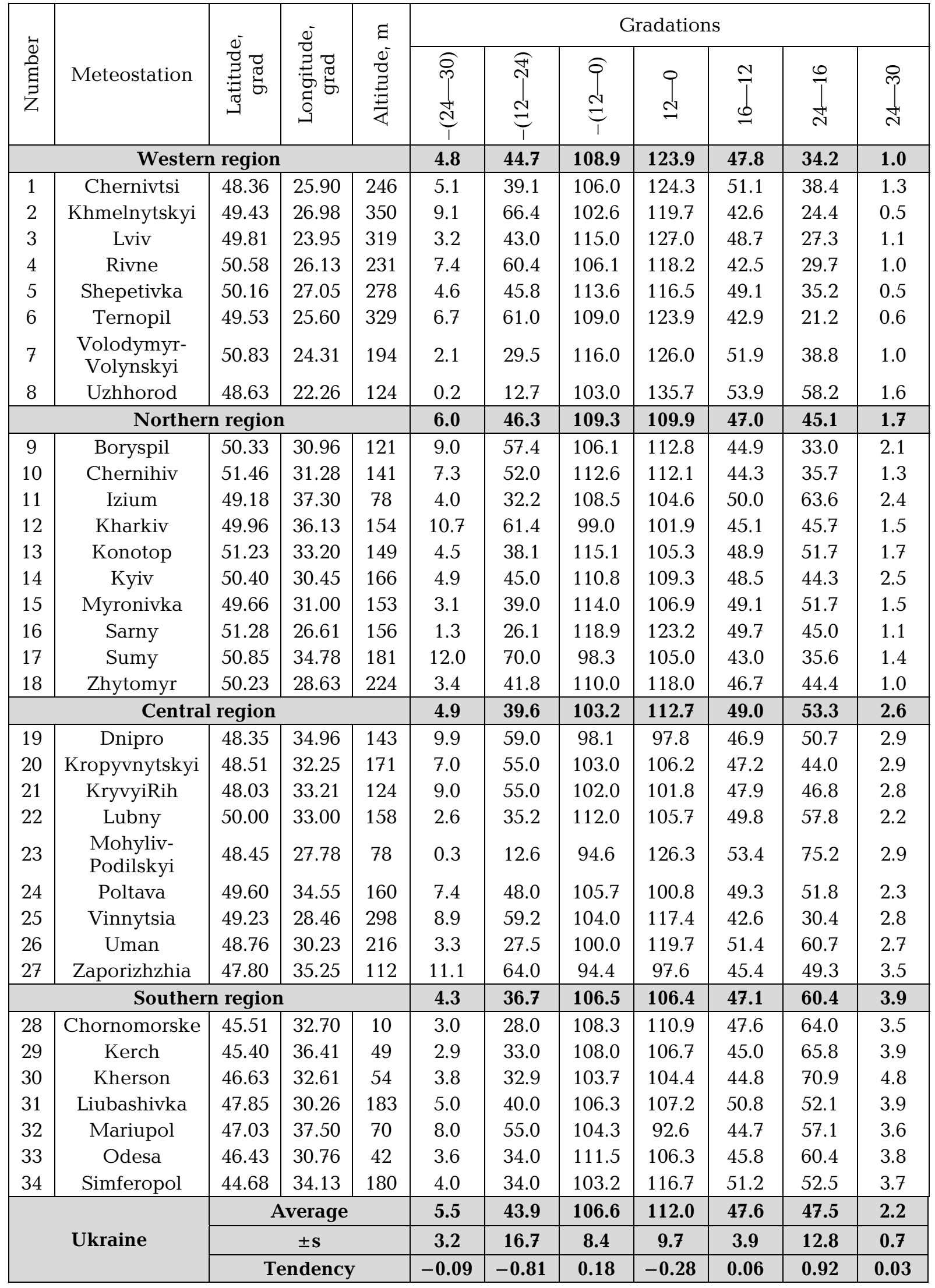


ghtly warm» (12-16) and «warm» (16-23) and, according to the heat sensation belong to subcomfortable and comfortable thermal conditions for human, consist of $48 \pm 8(\sim 13 \%)$ days per year each. Furthermore, in the Western region comfortable thermal conditions for human are observed only during $34 \pm 12$ days per year (due to high humidity and high wind speed that are typical for mountain regions). In the Northern and Central regions this number is $45 \pm 9$ and $52 \pm 14$ days per year respectively, while the Southern region has $60 \pm 8$ days per year (e. g. Kherson has 71 days per year and Crimea has 53 - 66 days).

The subcomfortable thermal conditions for human are almost evenly distributed over the territory of Ukraine and can be defined as more stable, since they have the least variability.

The "slightly warm» and "warm» gradations have on average $96 \pm 8(\sim 26 \%)$ days per year on the territory of Ukraine with apparent temperature for human assubcomfortable and comfortable.

Values $I_{\mathrm{EET}}$ that fall into gradation «hot» (23-30) have a small number of days (on the average $2 \pm 1(\sim 1 \%)$, while averaging the daily values of meteorological parameters over the past 30 years. However, in certain years and at certain meteorological stations up to 5-19 days per year in the gradation "hot» (with strong heat stress for human) were noted. On Fig. 2 shows the number of days $\left(N_{(23-30)}\right)$ at the selected meteostations for the period 1990 - 2020. The hottest years were 1998, 1999, 2001, 2002, 2007, 2010, 2012, 2016 and 2017. In particular years such weather conditions with $I_{\text {EET (23-30) }}$ were prevalent on more than $60-80 \%$ of the territory of Ukraine. Although in certain years such weather conditions were either not established or had low values (e. g. 1992-1995, 1997, 2003, 2013, 2018-2019).

It should be noted that the gradation «hot» can be defined more precise based on the analysis of maximum temperatures or fixed daily data of meteorological parameters, which has already been done in the research [Boychenko, Zabarna, 2019]. Additionally, other bioclimatic indices can be utilized, such as Universal thermal climate index (UTCI) that is widely used for hot climates [Teodoreanu, 2016; Napoli et al., 2018].

The tendency of thermal bioclimatic conditions changes in Ukraine. Over the last couple of decades, climate change in Ukraine has exceeded the global pace [Boychenko et al., 2016, 2018, Krakovska et al., 2018]. These changes were evidenced by a significant increase in temperature throughout the year, supported by aridization process. Warming during the cold period of the year, abnormally high temperatures in summer as well as significant variability of weather conditions affect heat sensation of a person, and influence consequently well-being, comfort and health of the population.

During the study period, stable tendencies in redistribution of weather conditions with regard to gradations were established. Namely, a decrease in the number of days falling into gradations "very cold» $-(30-23)$, «cold»-(23-12) and "slightly cool» $(0-12)$ for $-0.1,-0.8$ and -0.23 days per year respectively for the period 1991-2020 was noticed. The tendency of increase in the number of days is set for gradations " $\mathrm{COOl} »-(12-0)$, «slightly warm» $(12-16)$, "warm» $(16-23)$ and «hot» (23-30) for 0.2, 0.1, 0.9 and 0.03 days per year respectively. Moreover, the tendencies of redistribution by gradation appeared almost synchronously in all regions of Ukraine (see Fig. 1, b).

Spatial-seasonal distribution of comfortable thermal conditions for human. Indepth analysis of spatial-seasonal distribution of comfortable and subcomfortable thermal conditions for human at the selected meteorological stations for the period 1991-2020 was done.

The number of days with comfortable thermal conditions for human $\left(N_{(16-23)}\right)$ on the territory of Ukraine compose $48 \pm 13(13 \%)$ days per year,mainly in the warm period of the year, from April to October. The maximal number of days is typical for summer (June $11 \pm 3$, July $17 \pm 4$ and August $14 \pm 4$ days per month), while the minimal number is typical for spring and autumn about $3 \pm 2$ days per month (Fig. 3, a). However, $\left(N_{(16-23)}\right)$ values 


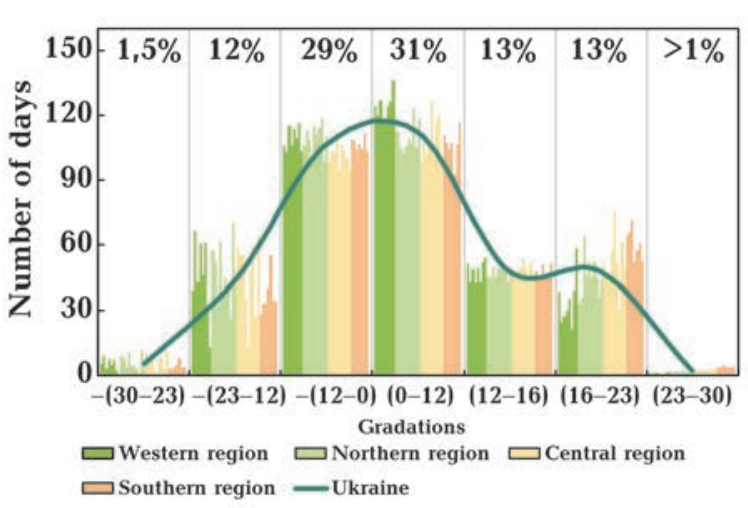

a

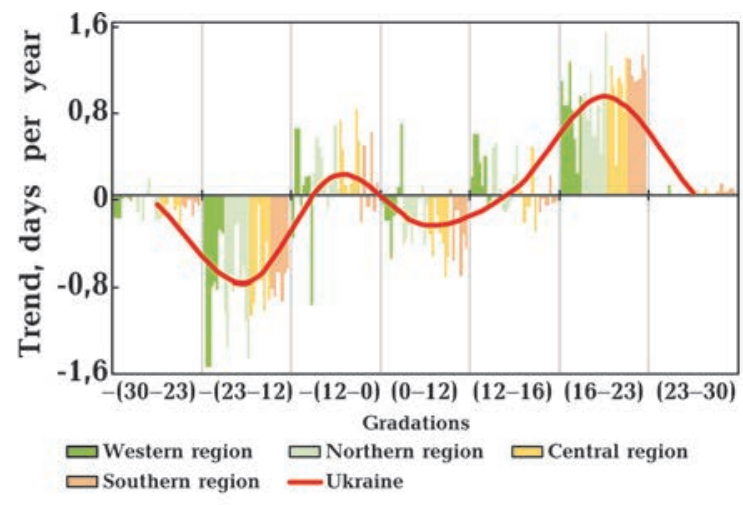

b

Fig. 1. Distribution of a number of days with thermal conditions for human due to $I_{\text {EET }}$ gradations ( $a$ ) and its trends $(b)$ in different regions and over the whole territory of Ukraine for the period 1991—2020.

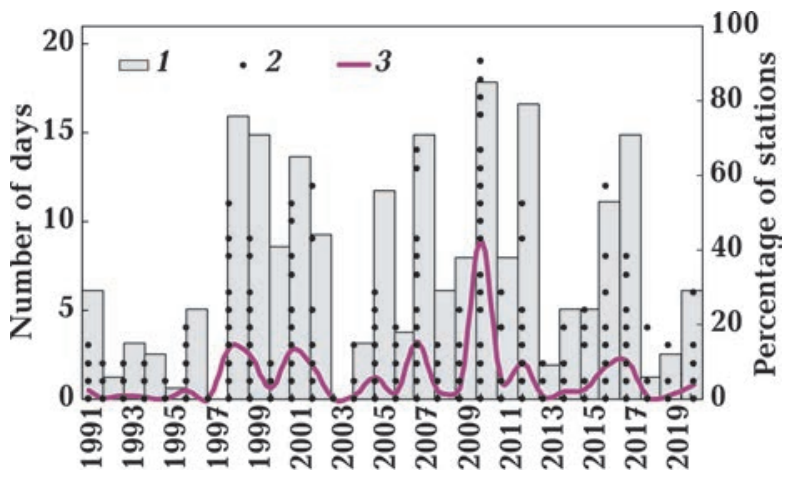

Fig. 2. Temporal distribution of days of «hot» gradation (23 - 30) on the territory of Ukraine for the period 1991 - 2020: 1 — percentage of stations where $I_{\text {EET }}$ values in this gradation were recorded, scale on the right; 2 - number of days in gradation for the particular meteostation; 3 - an average number of days per year, scale on the left.

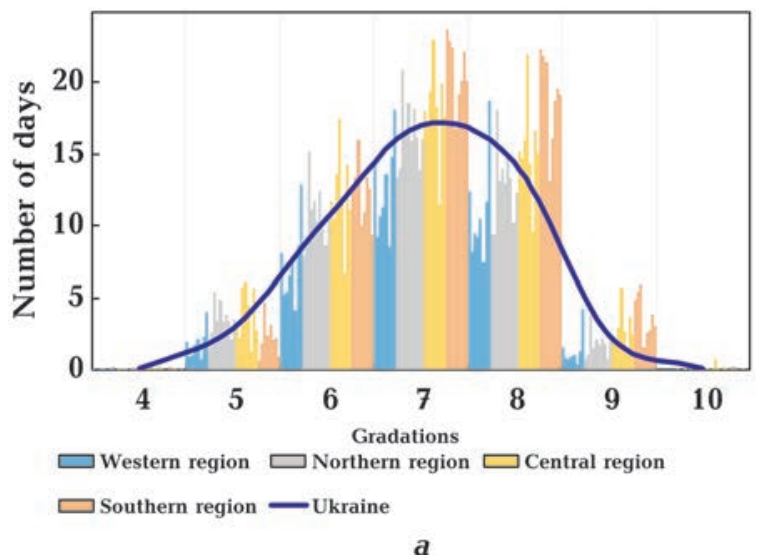

have some spatial differences, namely:

- Western region: June $7 \pm 3$, July $13 \pm 3$ and August $11 \pm 4$ days per month;

- Northern region: June $11 \pm 2$, July $16 \pm 2$ and August $13 \pm 3$ days per month;

- Central region: June $12 \pm 3$, July $18 \pm 4$ and August $15 \pm 4$ days per month;

- Southern region: June $13 \pm 2$, July $22 \pm 2$ and August $20 \pm 3$ days per month.

Likewise, on Fig. 4, $a$ there is a stable tendency to increase in a number of days with comfortable thermal conditions for human during the warm period almost in all regions of Ukraine for the last 30 years. The most significant tendencies of increase in $N_{(16-23)}$ values on $0.2-0.3$ days per month are typical for summers throughout the period 1991-2020.

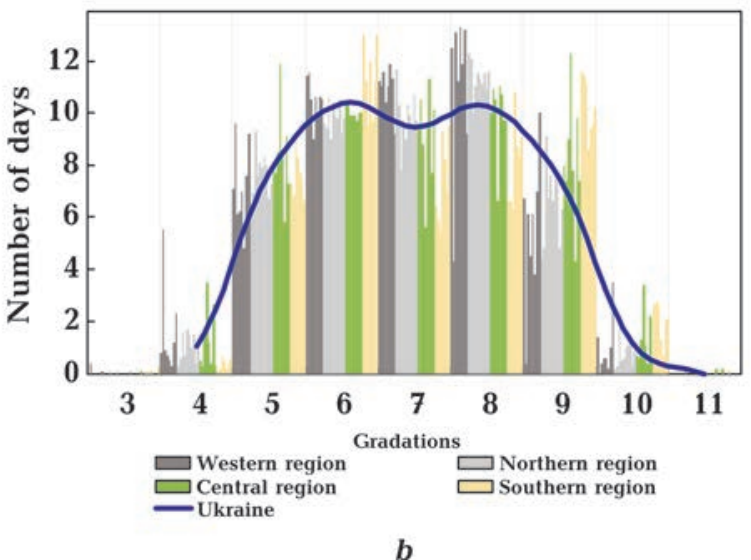

Fig. 3. Seasonal distribution of days with comfortable $(a)$ and subcomfortable (b) thermal conditions for human according to $I_{\mathrm{EET}}$ in different regions and over the whole territory of Ukraine for the period 1991-2020. 


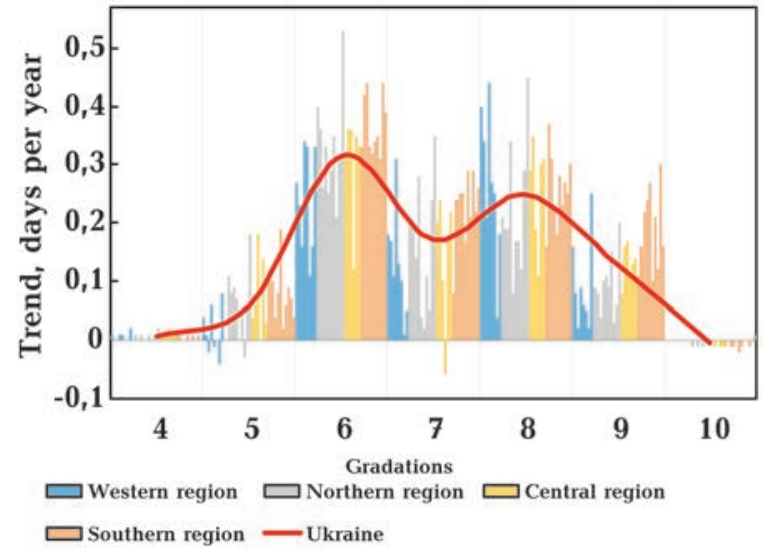

$\boldsymbol{a}$

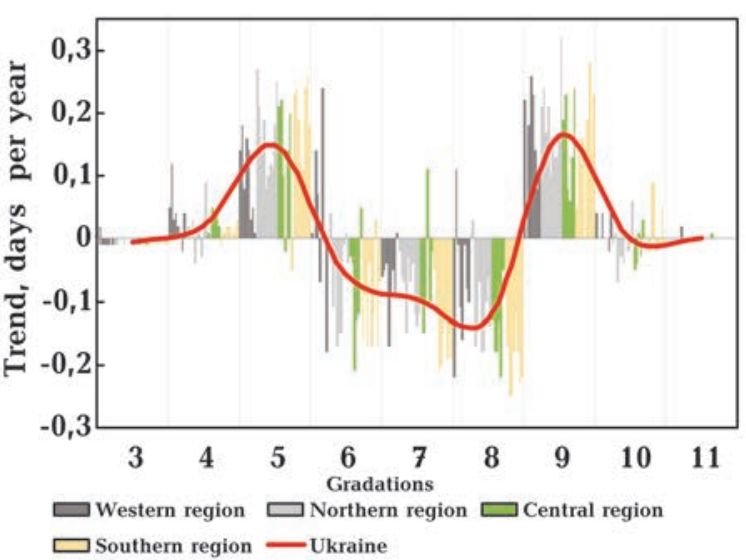

b

Fig. 4. Tendencies in alteration of seasonal distribution of days with comfortable ( $a$ ) and subcomfortable (b) thermal conditions for human according to $I_{\mathrm{EET}}$ in different regions and over the whole territory of Ukraine for the period 1991-2020.

On the average, $N_{(16-23)}$ values increased on $1-1.5$ weeks in a month over the territory of Ukraine. Further more, when assessing the trends, it was established that the number of days with comfortable thermal conditions for human increased on 0.83 days per year for the period 1991-2020 (about 25-30 days were added).

Subcomfortable thermal conditions for human $\left(N_{(16-23)}\right)$ on the territory of Ukraine is also represent by $48 \pm 3$ (13\%) days per year. Moreover, for May-September this number is almost equal, from 6 to 11 days per month, while the minimal values were identified in April, October and November of about $1-2$ days (see Fig. $3, b) . N_{(16-23)}$ values have some spatial differences, namely:

- Western region: May $7 \pm 2$, June $11 \pm 1$, July $11 \pm 3$, August $11 \pm 3$ and September $6 \pm$ \pm 1 days per month;

- Northern region: May $8 \pm 1$, June $10 \pm 1$, July $11 \pm 1$, August $11 \pm 1$ and September $7 \pm$ \pm 2 days per month;

- Central region: May $8 \pm 2$, June $10 \pm 1$, July $10 \pm 1$, August $11 \pm 2$ and September $8 \pm$ \pm 2 days per month;

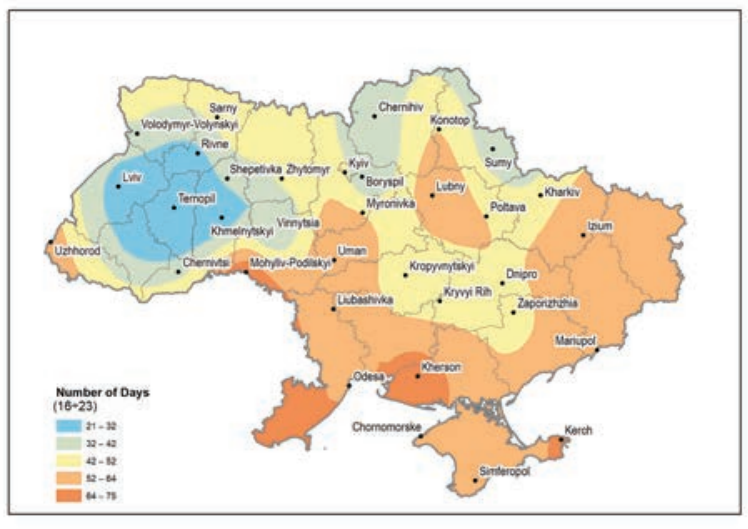

a

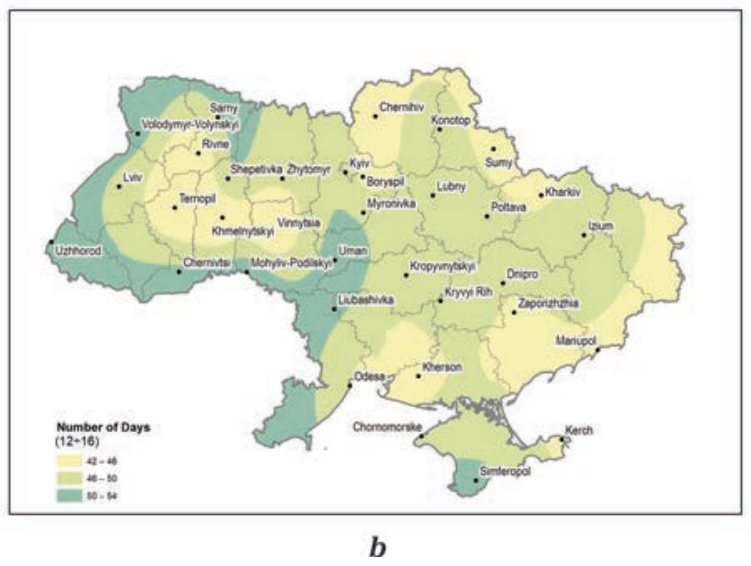

Fig. 5. Spatial distribution of days with comfortable $(a)$ and subcomfortable $(b)$ thermal conditions for human according to $I_{\mathrm{EET}}$ over the whole territory of Ukraine, averaged for the period 1991—2020. 
- Southern region: May $8 \pm 1$, June $11 \pm 1$, July $8 \pm 2$, August $8 \pm 2$ and September $10 \pm 1$ days per month.

On Fig. $4, b$ there is an increase in $N_{(12-16)}$ values on $0.02-0.16$ for the last 30 years with a slight decrease in June and August on -0.1 days per month for the same period. When accessing the changing tendency, $N_{(12-16)}$ increased on only 0.05 days per year for the period 1991-2020.

The spatial distribution of days with comfortable and subcomfortable thermal conditions for human due to averaged $I_{\mathrm{EET}}$ values for the period $1991-2020$ on the territory of Ukraine is shown on Fig. 5.

Thus, during the warm period of the year the numbers of days with comfortable and subcomfortable thermal conditions for human on the territory of Ukraine have a tendency to increase in spatial-temporal distribution over the territory (with some regional differences). However, despite an increase in comfortable and subcomfortable thermal conditions for human, the manifestation of abnormally high temperatures in summer is also noted.

Discussion. Climate change impact patterns on comfortable thermal conditions for human in Ukraine. The vulnerability of human health to climate change can be defined as a function of sensitivity to changes in weather and climate, an exposure to the weather or climate hazard, characteristics of the population (development level and demographic structure) and a state of the local environment [WHO ..., 2003].

Climate changes on the territory of Ukraine in the $20^{\text {th }}$ century and the beginning of the $21^{\text {st }}$ century were characterized by an increase in surface air temperature by $1.2 \pm 0.2 \% / 100$ years, while in $20^{\text {th }}$ century this increase was only by $0.6 \pm 0.1 \% / 100$ years [Boychenko et al., 2018, Krakovska et al., 2018]. Nevertheless, climate change in Ukraine has spatial differences, e.g. in the northern, north-eastern and north-western regions warming is more intense $(\Delta T=1.7 \pm 0.4 \% / 100$ years $)$ with a decrease in the amount of precipitations by $10-15 \% / 100$ years. On the contrary, in the southern, south-eastern and south-western regions the temperature rise is less intense $(\Delta T=$
$=0.8 \pm 0.3 \% / 100$ years $)$, with a slight increase and sometimes even a decrease in precipitations within 5-7 \%/100 years.

Over the last couple of decades an increase in the frequency of abnormally high summer temperatures supported by aridification process is noted, as well as abnormally warm winters with increased variability of weather conditions and precipitations mainly in the form of rain or sleet [Boychenko et al., 2016]. Such climatic conditions have a negative impact on the well-being, comfort and health of the population. In [WHO ..., 2005] it is stated that in temperate latitudes due to seasonality, mortality and morbidity rates among the population increase, while in the tropical climate, the level of seasonal mortality is significantly lower. Manifestations of seasonality in the climate of temperate latitudes and significant variability of weather conditions during the cold season have considerable impact on human health.

Weather conditions with apparent temperature of very cold — cold — Cool—-slightly cool compose about $268 \pm 9$ (73\%) days per year that consequently lead to emergence of physiologically cold stress for a prevalent part of population in Ukraine (extreme cold-strong cold-moderate cold - slight cold stress).

On the average, across the territory of Ukraine, the largest numbers of days fall into gradations slightly cool $(0-12)$ and cool $-(12-0), 113 \pm 10(31 \%)$ and $107 \pm 8(29 \%)$ days per year respectively. Weather conditions (slightly cool) are typical mainly for autumn and spring and also partially for winter, while cool $-(12-0)$ is more typical for winter and partially for autumn and spring.

Changes in temperature below or above $0{ }^{\circ} \mathrm{C}$ during several days (with an increasing effect of «temperature swing») can cause serious deteriorations in people's well-being, an exacerbation of chronic diseases, especially connected to cardiovascular system [MartiSoler et al., 2014].

Comfortable and subcomfortable thermal conditions for human with apparent temperature of slightly warm and warm compose on the average $96 \pm 8(\sim 26 \%)$ days per year on the territory of Ukraine, with the stable tendency 
to increase over the past 30 years by $25-30$ days per year. It creates more comfortable climatic conditions for the local population at a certain period of the year. The comfortable thermal conditions for human on the territory of Ukraine is represented by $48 \pm$ $\pm 14(13 \%)$ days per year during the warm period from April to October, with maximum in summer:June $11 \pm 3$, July $17 \pm 4$ and August $14 \pm 4$ days per month.

It should be noted that in recent decades, the frequency of hot and very hot apparent temperature (23-30) as well as temperatures above $30^{\circ} \mathrm{C}$ has increased significantly during the summer period and can cause strong and extreme heat stress for human. Such abnormally hot climatic conditions will be analyzed more detailed in our future studies.

For temperate latitudes, depending on the quantity of days per month that fall into $N_{(16-23)}$ gradation, the degree of a comfortable climatic resource in a region can be identified: $30 \%$ - minimal, 30-50\% - sufficient, 50-70\% - optimal, more than $70 \%$ — the most optimal [Isayev, 2001, Vitchenko et al., 2017]. Thus, in June-August, the climatic conditions of Ukraine have a certain comfortable climatic resource:

- Western region - minimal climatic resource (23-40\%)and in particular years sufficient;

- Northern region - sufficient climatic resource $(36-53 \%)$ and in particular years optimal;

- Central region - sufficient climatic resource $(40-60 \%)$ and in particular years the most optimal;

- Southern region - sufficient climatic resource (40-67\%) and in particular years the most optimal.

Conclusions. Environmental and climatic conditions with pronounced seasonality and variability, abnormal summer heat as well as regional climate change, have a certain negative impact on well-being, health and comfort of life of population in the region. To assess the climatic comfort of a person, a bioclimatic index (equivalent-effective temperature) was used, which allows to evaluate thermal sensation of a person under a certain combination of meteorological parameters. In this study we used daily observation data (surface air temperature, air humidity and wind velocity) at 34 meteorological stations in Ukraine for the period 1991 - 2020. Calculated values of the indices, which characterize the thermal bioclimatic conditions, were ranked and analyzed.

It was found that weather conditions with apparent temperature of very cold - coldcool—slightly cool compose about $268 \pm 9$ (73 \%) days per year. Thus, the population of Ukraine experience conditions of physiologically cold stress (extreme cold-strong coldmoderate cold — slight cold stress) during the prevalent time of the year. Weather conditions that fall into gradations very cold $-(30-23)$ and cold $-(23-12)$ represent $6 \pm 5(\sim 2 \%)$ and $42 \pm 17(\sim 12 \%)$ days per year, respectively. This weather conditions can consequently cause extreme cold and strong cold stress and have a tendency towards decreasing repeatability.

The largest numbers of days on the average across the country have such gradations as

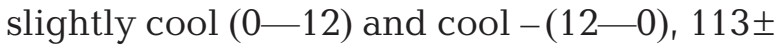
$\pm 10(31 \%)$ and $107 \pm(29 \%)$ days per year respectively. Slightly cool weather conditions are typical for the warm period of the year, mainly autumn and spring, and partially winter, while cool gradation - $(12-0)$ is more prevalent in winter, autumn and spring seasons.

Comfortable and subcomfortable thermal conditions for human with apparent temperature of slightly warm and warm compose on the average $96 \pm 8$ ( $26 \%)$ days per year. Comfortable thermal conditions for human on the territory of Ukraine are represented by $47 \pm$ $\pm 13(13 \%)$ days per year and are typical for the warm period of year from April to October, with maximal values in summer: June $10 \pm 3$, July $17 \pm 4$ and August $15 \pm 4$ days per month. A number of days with subcomfortable thermal conditions for human on the territory of Ukraine compose also $48 \pm 3$ (13\%) days per year. Moreover, for May-September it has almost an equal number of days per month from 7 to 12 with minimal values in April, October and November of about $1-2$ days.

There is a significant tendency to increase in the number of days with comfortable thermal conditions for human in summer by $0.2-$ 
0.3 days per month for the period 1991-2020. The trend is 0.83 days per year (on average 25-30 days were added each year) for the period 1991-2020. It contributes to creation of more comfortable climatic conditions for the local population in a certain period of the year.

It should be noted that over the last couple of decades, especially during the summer period, the frequency of hot apparent temperatures (23-30) has increased, which can subsequently cause strong and extreme heat stress for humans. In particular years, it was recorded up to 5-19 days per year.

\section{References}

Blazejczyk, K., Epstein, Y., Jendritzky, G., Staiger, H., \& Tinz, B. (2012). Comparison of UTCI to selected thermal indices. International Journal Biometeorology, 56, 515-535. https://doi. org/10.1007/s00484-011-0453-2.

Boer, E., de Beurs, K., \& Dewi, H. (2001). Kriging and thin plate splines for mapping climate variables. International Journal of Applied Earth Observation and Geoinformation, 3, 146-154. https://doi.org/10.1016/S0303-2434(01)85006-6.

Boychenko, S., Voloshchuk, V., Kuchma, T., \& Serdyuchenko, N. (2018). Long-time changes of the thermal continentality index, the amplitudes and the phase of the seasonal temperature variation in Ukraine. Geofizicheskiy Zhurnal, 40(3), 81-96. https://doi.org/10.24028/ gzh.0203-3100.v40i3.2018.137175.

Boychenko, S., Voloshchuk, V., Movchan,Ya., Serdjuchenko, N., Tkachenko, V., Tyshchenko, O., \& Savchenko, S. (2016). Features of climate change on Ukraine: scenarios, consequences for nature and agroecosystems. Proc. of the National Aviation University, 4, 96-113. https://doi.org/10.18372/2306-1472.69.11061.

Boychenko, S., \& Zabarna, O. (2019). Estimation of comfort of weather conditions and trends of their changes for the Kyiv region in the conditions of climate change. Geofizicheskiy Zhurnal, 41(6), 128-143. https://doi.org/10.24028/ gzh.0203-3100.v41i6.2019.190071(in Ukraiian).

Cajoto V., Peromingo, D., Vicedo, V., Leira, S., Suarez, G., Frojan, S., \& Gallego, I. (2005). Health impact of 2003 heat wave at Hospital de Riveira (A Coruña). Anales de Medicina Interna, 22(1), 15-20. https://doi.org/10.4321/s 0212-71992005000100004.
For that reason, the climatic conditions of Ukraine have a certain potentially comfortable climatic resource in June-August, with a certain variability: western region has a minimal climatic resource (23-40\%) and a sufficient one sin some particular years; northern region has a sufficient climatic resource $(36-53 \%)$ and an optimal ones in some years; central region has an optimal climatic resource $(40-60 \%)$ and the most optimal ones in some years; southern region has an optimal climatic resource (40-67\%) and the most optimal ones in some years.

Canoui-Poitrine, F., Cadot, E., \& Spira, A. (2006). Excess deaths during the August 2003 heat wave in Paris, France. Revue d'E pidémiologie et de SantéPublique, 54(2), 127 -135. https:// doi.org/10.1019/200601173.

Cheung, C., \& Hart, M. (2014). Climate change and thermal comfort in Hong Kong. International Journal of Biometeorology, 58(2), 1-12. https://doi.org/10.1007/s00484-012-0608-9.

Gremy, I., Lefranc, A., \& Pepin, P. (2004). Impact of the August 2003 heat wave: sanitary consequences in Ile-de-France. Revue d'Epidémiologie et de Santé Publique, 52, 93-98. https:// doi.org/10.1080/00324720701804249.

Fanger, P. (1970). Thermal Comfort:analysis and applications in environmental engineering. Copenhagen: Danish Technical Press, 244 p.

Franke, R. (1982). Smooth Interpolation of Scattered Data by Local Thin Plate Splines. Computer and Mathematics with Applications, 8(4), 273-281. https://doi.org/10.1016/0898-1221 (82)9 009-8.

Huang, Y., Lai, D., Liu, Y., \& Huang, X. (2020). Impact of climate change on outdoor thermal comfort in cities in United States. Web of Conferences 158, 01002.

Epstein, Y., \& Moran, D. (2006). Thermal Comfort and the Heat Stress Indices. Industrial Health, 44, 388-398. https://doi.org/10.2486/ indhealth.44.388.

IPCC: Climate change 2013: The Physical Science Basis. (2013). Working Group I Contribution to the Fifth Assessment Report of the Intergovernmental Panel on Climate, UNEP/ WMO. Retrieved from: http://www.ipcc.ch/report/ar5/wg1/. 
Isayev, A. (2001). The Ecological Climatology. Moscow: NauchnyyMir, 456 p. (in Russian).

Jendritzky, G., \& Tinz, B. (2009). The thermal environment of the human being on the global scale. Global Health Action, 2(1), 1-12. https: //doi.org/10.3402/gha.v2i0.2005.

Johnson, H., Kovats, R., McGregor, G., Stedman, J., Gibbs, M., Walton, H., Cook, L., \&Black, E. (2005). The impact of the 2003 heat wave on mortality and hospital admissions in England. Health Statistics Quarterly, 25, 6-11.

Koffi, B., \& Koffi, E. (2008). Heat waves across Europe by the end of the 21st century: Multiregional climate simulations. Climate Research, 36, 153-168. https://doi.org/10.3354/cr00734.

Kovats, R., \& Hajat, S. (2008). Heat Stress and Public Health: A Critical Review. Annual Review of Public Health, 29, 41-55. https://doi. org/10.1146/annurev.publhealth.29.020907. 090843.

Krakovska, S.V., Palamarchuk, L.V., Gnatiuk, N.V., \& Shpytal, T.M. (2018). Projections of air temperature and relative humidity in Ukraine regions to the middle of the 21 st century based on regional climate model ensembles. Geoinformatika, 3(67), 62-77 (in Ukrainian).

Lemonsu, A., Beaulant, A., Somot, S., \& Masson, V. (2014). Evolution of heat wave occurrence over the Paris basin (France) in the 21st century. Climate Research, 61, 75-91. https://doi.org/10.33 54/cr01235.

Marti-Soler, H., Gonseth, S., Gubelmann, C., Stringhini S., Bovet, P., Chen, P.-C., Wojtyniak, B., Paccaud, F., Tsai, D.-H., Zdrojewski, T., \& Marques-Vidal, P. (2014). Seasonal variation of overall and cardiovascular mortality: a study in 19 countries from different geographic locations. PLoS One, 9(11), e113500. https://doi. org/10.1371/journal.pone.0113500.

Matzarakis, A., \& Amelung, B. (2008). Physiological Equivalent Temperature as Indicator for Impacts of Climate Change on Thermal Comfort of Humans. In Seasonal Forecasts, Climatic Change and Human Health, Ed. M.C. Thomson, R. Garcia-Herrera, and M., Beniston, 161172. Springer Science.

Milovanović, B., Radovanović, M., Stanojević, G., Pecelj, M., Nikolić, J. (2017). Climate of Serbia. In M. Radovanović (Ed), Geography of Serbia. Beograd, Geographical Institute (pp. 94-156) (in Serbian).

Missenard, F. (1933) Température effective d'une atmosphere Généralisationtempératurerésultante d'un milieu. In: EncyclopédieIndustrielle et Commerciale, Etude physiologique et technique de la ventilation (pp. 131-185). Librerie de l'Enseignement Technique, Paris.

Napoli, C., Pappenberger, F., \& Cloke, H. (2018). Assessing Heat-related Health Risk in Europe via the Universal Thermal ClimateIndex(UTCI). International Journal of Biometeorology, 62(7), 1155 - 1165. https://doi.org/10.1007/s00484018-1518-2.

Pecelj, M. (2012). Bioclimatic Indices Based on the Menex Model Example on Banja Luka. Proceedings of the Geographical Institute «Jovan Cvijić», 63(1), 1-10.

Pecelj, M., Krajić, A., Trbic, G., Stefanović, V., \& Golijanin, J. (2013). Bioclimatic characteristics of the city of Novi Sad based on human heat balance. Proc. 6th International Conference on Climate Change, Global Warming and Biological Problems, Recent Advances in Environmental Science, Cyprus (pp. 244-249).

Poumadere, M., Mays, C., Mer, S., \& Blong, R. (2005). The 2003 Heat Wave in France: Dangerous Climate Change Here and Now. Risk Analysis, 25(6), 1483-1494. https://doi.org/10.1111 /j.1539-6924.2005.00694.x.

Rymuza, K., Radzka, E., \& Świerzycka, G. (2019). Assessment of Variation in Thermal Sensations Determined Based on Effective Temperature. Journal of Ecological Engineering, 20(2), 218225. https://doi.org/10.12911/22998993/93797.

Teodoreanu, E. (2016). Thermal Comfort Index. Present Environment and Sustainable Development, 10(2), 105-118. https://doi.org/10.1515/ pesd-2016-0029.

Thorsson, S., Lindberg, F., Björklund, J., Holmer, B. \& Rayner, D. (2011). Potential changes in outdoor thermal comfort conditions in Gothenburg, Sweden due to climate change: the influence of urban geometry. International Journal of Climatology, 31(2), 324-335. https://doi.org /10.1002/joc.2231.

Vitchenko, A., \& Telesh, I. (2017). Current trends of the climatic comfort change in Minsk. J. Belarus. State Univ. Geogr. Geol., 2, 103-113. Retrieved from https://elib.bsu.by/bitstream/123 456789/185579/1/103-113.pdf (in Russian).

World Weather. (2021). Retrieved from https://en. tutiempo.net.

Weather for 243 countries of the world. (2021). Retrieved from http://rp5.ua. 
WHO: Methods for assessing the sensitivity of human health and adapting public health to climate change. (2005). Publications WHO Regional Office for Europe. Retrieved from https: //apps.who.int/iris/handle/10665/276959.
WHO: Methods of assessing human health vulnerability and public health adaptation to climate change. (2003). Retrieved from https:// www.-euro.who.int/_data/assets/pdf_file/0009/ 91098/E81923.pdf.

\title{
Комфортні кліматичні умови на території України за період $1991-2020$ рp.
}

\author{
С. Бойченко ${ }^{1,2}$, О. Забарна ${ }^{3}$, Т. Кучма ${ }^{4}, 2021$ \\ ${ }^{1}$ Інститут геофізики імені С.І. Субботіна НАН України, Київ, Україна \\ ${ }^{2}$ Національний університет «Києво-Могилянська академія», Київ, Україна \\ ${ }^{3}$ Центрально-Свропейський університет, Будапешт, Угорщина \\ ${ }^{4}$ Інститут агроекології і природокористування, Київ, Україна
}

\begin{abstract}
Екологічний стан довкілля, кліматичні умови з вираженою сезонністю та мінливістю, аномальна літня спека та регіональні прояви змін клімату мають певний негативний вплив на добробут, здоров'я та комфортність життя населення країни. Аля оцінювання кліматичного комфорту використано біокліматичний індекс (індекс еквівалентноефективних температур), що дає змогу оцінити тепловідчуття людини за певної комбінації метеорологічних параметрів. У дослідженні використано дані щоденних спостережень (приземна температура, відносна вологість повітря та швидкість вітру) для 34 метеостанцій України за період 1991-2020рр. Проведено ранжування та аналіз показників, що характеризують теплові біокліматичні умови.

Установлено, що погодні умови з тепловідчуттям дуже холодні-холодні-прохолодні-злегка прохолодні становлять $268 \pm 9$ (73\%) днів на рік. Отже, населення України проживає в умовах фізіологічного холодного стресу більшу частину року. Погодні умови, які підпадають під градації, дуже холодні - (30-23) та холодні - (23-12), становлять $6 \pm 5$ $(\sim 2 \%)$ та $42 \pm 17$ ( 12\%) днів на рік відповідно і спричиняють тепловідчуття сильного холоду та сильного холодного стресу і мають тенденцію до зменшення через зміни клімату.

Найбільша кількість днів у середньому по країні припадає на градації з погодними умовами - злегка прохолодні (0-12) та прохолодні - (12-0), $113 \pm 10$ (31\%) та $107 \pm 8$ (29\%) днів на рік відповідно. Злегка прохолодні умови характерні для теплого періоду року, переважно осені та весни, частково зими, тоді як прохолодні частіше переважають у зимовий, осінній та весняний сезони.

Комфортні та субкомфортні умови для людини з тепловідчуттям злегка теплі й теплі становлять у середньому $96 \pm 8(\sim 26 \%)$ днів на рік. Комфортні умови становлять близько $47 \pm 13$ (13\%) днів на рік і характерні для теплого періоду з квітня по жовтень, 3 максимальними значеннями влітку: у червні $-10 \pm 3$, у липні $-17 \pm 4$, у серпні 15 днів \pm 4 дні на місяць. Кількість днів із субкомфортними умовами становить $48 \pm 3$ (13\%) днів на рік, з майже однаковою кількістю днів на місяць з 7 по 12 в травні-вересні та з мінімальними значеннями у квітні, жовтні та листопаді, приблизно $1-2$ дні. Встановлено тенденцію до збільшення кількості днів із комфортними умовами влітку на $0,2-0,3$ дня на місяць, а також щорічний приріст на 0,83 дня на рік (у середньому додалось 25-30 днів) за період 1991-2020 рр. Отже, комфортність кліматичних умов для місцевого населення на території України зростає в теплий період року.

Однак зросла повторюваність аномально високих температур, особливо в літній період, що підпадають до градації (23-30), що спричиняє сильний тепловий стрес Аля людини (у певні роки зафіксовано до 5-19 днів на рік).

Таким чином, кліматичним умовам України властивий певний потенційно комфортний кліматичний ресурс (у червні-серпні): у Західному регіон — мінімальний (23 $40 \%$ ); у Північному регіоні - достатній (36-53\%); у Центральному регіоні - оптимальний (40-60\%), у Південному регіоні — оптимальний (40-67 \%).
\end{abstract}

Ключові слова: кліматичні зміни, еквівалентно-ефективна температура, комфортні та субкомфортні погодні умови, тенденції. 


\title{
Комфортные климатические условия на территории Украины за период 1991 - 2020 гг.
}

\author{
С. Бойченко ${ }^{1,2}$, А. Забарна ${ }^{3}$, T. Кучма ${ }^{4}, 2021$
}

${ }^{1}$ Институт геофизики имени С.И. Субботина НАН Украины, Киев, Украина

${ }^{2}$ Национальный университет «Киево-Могилянская академия», Киев, Украина

${ }^{3}$ Центрально-Европейский университет, Будапешт, Венгрия

${ }^{4}$ Институт агроэкологии и природопользования, Киев, Украина

\begin{abstract}
Экологическое состояние окружающей среды, климатические условия с выраженной сезонностью и изменчивостью, аномальная летняя жара и региональное проявление изменений климата имеют определенное негативное влияние на благосостояние, здоровье и комфортность населения страны. Аля оценки климатического комфорта использован биоклиматический индекс (индекс эквивалентноэффективных температур), что позволяет оценить теплоощущения человека по определенной комбинации метеорологических параметров. В исследовании использованы данные ежедневных наблюдений (приземная температура, относительная влажность воздуха и скорость ветра) для 34 метеостанций Украины за период 1991-2020 гг. Проведены ранжирование и анализ показателей, характеризующих
\end{abstract} тепловые биоклиматические условия.

Установлено, что погодные условия с теплоощущением очень холодные-холодные-прохладные - слегка прохладные составляют $268 \pm 9$ дней $(73 \%)$ в году. Следовательно, население Украины проживает в условиях физиологического холодного стресса большую часть года. Погодные условия, которые подпадают под градации, очень холодные - $(30-23)$ и холодные - $(23-12)$, составляют $6 \pm 5(\sim 2 \%)$ и $42 \pm 17$ $(\sim 12 \%)$ дней в году соответственно, вызывают теплоощущения сильный холод и сильный холодный стресс и имеют тенденцию к уменьшению из-за измененя климата.

Наибольшее количество дней в среднем по стране приходится на градации с погодными условиями слегка прохладные $(0-12)$ и прохладные - $(12-0), 113 \pm 10$ (31 \%) и $107 \pm 8(29 \%)$ дней в году соответственно. Слегка прохладные условия характерны Аля теплого периода года, преимущественно осени и весны, частично зимы, тогда как прохладные чаще преобладают в зимний, осенний и весенний сезоны.

Комфортные и субкомфортных условия для человека с теплоощущениями слегка теплые и теплые составляют в среднем $96 \pm 8(\sim 26 \%)$ дней в году. Комфортные условия составляют около $47 \pm 13(13 \%)$ дней в году и характерные Аля теплого периода с апреля по октябрь, с максимальными значениями летом: в июне $10 \pm 3$, в июле $17 \pm 4$, в августе 15 дней \pm 4 дня в месяц. Количество дней с субкомфортных условиями составляет $48 \pm 3(13 \%)$ дней в году, с почти равным количеством дней в месяц с 7 по 12 в мае-сентябре и с минимальными значениями в апреле, октябре и ноябре, примерно 1-2 дня. Установлена тенденция к увеличению количества дней с комфортными условиями летом на 0,2-0,3 дня в месяц, а также ежегодный прирост на 0,83 дня в год (в среднем прибавилось 25-30 дней) за период 1991-2020 гг. Итак, комфортность климатических условий для местного населения на территории Украины возрастает в теплый период года.

Однако увеличилась повторяемость аномально высоких температур, особенно в летний период, относящихся к градации (23-30), что вызывает сильный тепловой стресс для человека (в определенные годы зафиксировано 5-19 дней в году).

Таким образом, климатические условия Украины обладают определенным потенциально комфортным климатическим ресурсом (в июне-августе): Западный регион - минимальным (23-40 \%); Северный регион - достаточным (36-53 \%); Центральный регион - оптимальным (40-60\%), Южный регион - оптимальным (40-67\%).

Ключевые слова: климатические изменения, эквивалентно-эффективная температура, комфортные и субкомфортные погодные условия,тенденции. 